\title{
Financial Management Practices and Performance of Small and Medium Scale Poultry Industry in Ogun State, Nigeria
}

\author{
Adegbie Festus Folajinmi, Alawode Olufemi Peter
}

Department of Accounting, Babcock University, Ilishan-Remo, Nigeria

Email address:

Olufemi.alawocome@gmail.com (A. O. Peter)

\section{To cite this article:}

Adegbie Festus Folajinmi, Alawode Olufemi Peter. Financial Management Practices and Performance of Small and Medium Scale Poultry Industry in Ogun State, Nigeria. Journal of Finance and Accounting. Vol. 8, No. 2, 2020, pp. 90-106. doi: 10.11648/j.jfa.20200802.15

Received: March 13, 2020; Accepted: March 30, 2020; Published: May 14, 2020

\begin{abstract}
Small and Medium-Sized Enterprises (SMEs) and the Agricultural sector is a combination that constitute a recognisable driving force for the development of an economy and the contribution of this sector cannot in any way be overlooked by any developing country particularly one that is struggling to diversify from petrol-carbon revenue and generate employment. The efficiency or otherwise of applicable financial management practices combined with the peculiarity and uncertainty of the business environment can make or mar the success of such SMEs operating in the poultry industry and this is the focus of this study. The study employed survey design. The study population comprised Poultry farmers in 162 farms as registered with the Poultry Association of Nigeria-Ogun State Chapter with the total of 200 farm managers, excluding farm attendants and other non-managerial staff. The Cochran formula was used to obtain a sample size of 150 . The owners/managers of these Poultry farms were selected through a multi-stage sampling technique which involves the stratified, proportionate, and simple random sampling method. The instrument validity was established through scrutiny and evaluation by the research supervisors and experts in the study area, and reliability was determined via Cronbach's alpha coefficient computed from pilot study responses. By the use of instrument codes, responses were processed into quantitative data for descriptive and empirical analysis. The analysis revealed that all proxies of financial management practices such as annual budget process, capital structure management and working capital management have a significant positive effect on profitability of poultry industry (Adjusted $R^{2}=0.258, F$-statistics $=9.407 .: p=0.000<0.05$ ). Thus, the study concluded that financial management practices proxies, of profitability, cash solvency and economic value added, has a significant positive effect on the performance of poultry industry in Ogun State, Nigeria.
\end{abstract}

Keywords: Poultry Industry, Annual Budget Process, Capital Structure Management, Liquidity, Profitability, Working Capital Management

\section{Introduction}

\subsection{Background}

In the present dynamic, fast-changing, High-Tech impacted and intense global competitive environment, the importance of financial management practices manifests in its rapid diffusion on the Livestock industry and generally on Small and Medium Enterprises (SMEs) growth and development. Salavou et al [59] established that majority of these farms failed due to poor management of their financial activities. Financial management practices are considered as a critical requirement for entrepreneurial development, product development, growth and profitability of SME farms.
For SMEs operating in a global dynamic competitive market to achieve growth, development and profitability, financial management practices are often a condition for survival [44]. Poultry farms as a sub-set of the Livestock industry are farms that raise chickens (layers, broilers, cockerels and noilers), ducks, turkeys, and other birds for meat and egg production. In the past, poultry farming involved raising chickens mainly in the agrarian farms or in the back yard for daily egg production and family consumption. However, poultry farming today is a huge business that is split into several operations including hatcheries, poultry services and veterinary services, other inputs suppliers, pullet farms for meat and egg production (NPS 2018).

The Nigerian poultry industry in particular has been 
rapidly expanding in recent years and is therefore one of the most commercialized (capitalized) subsectors of Nigerian agriculture [40]. The popularity of poultry production can be explained by the fact that poultry has many advantages over other livestock. Poultry birds are good converters of feed into useable protein in meat and eggs. The production costs per unit remain relatively low, and the return on investment is high. Therefore, farmers need a relatively small amount of capital to start a poultry farm. Furthermore, poultry meat is tender and the acceptability to consumers is high, regardless of their religious beliefs. Also, the production cycle is not long, so capital is not tied up over a long period. Eggs, as one of the major products of poultry production, are more affordable for the common person than other sources of animal protein [28].

Despite these positive aspects, poultry production has not been keeping pace with rapidly increasing domestic consumption. The domestic shortfall is estimated at 25,000 MT per annum (USDA 2002). This lagging increase in domestic production can be explained by the fact that most producers in Nigeria are like in other businesses faced with the twin lines of technical and financial management challenges. Technically, these farming systems are characterized by outdated barn equipment and production techniques and inadequate hygiene management. In addition, producers suffer from a weak feed industry and poor market access as a result of inadequate infrastructure [6]. Improvements in breeding, husbandry, and management are needed to increase the efficiency in chicken production, which will lead to lower production costs [2].

Commercially, poultry farming is characterized by higher demands on capital and labour, poor financial management practices and dearth of modern financial supporting tools. Improvements in breeding, husbandry, and management are needed to increase the efficiency in chicken production, which will lead to lower production costs [2]. The management problems include a low capital base, the resulting lack of equity capital, inefficient management, technical and economic inefficiencies, infection with diseases and parasites, high costs for feeds, poor quality of day-old chicks, and inadequate extension and training facilities $([6,49])$. Thus, there seems to be untapped potential for improvements in poultry production in Nigeria from both a production and an economic point of view.

Poultry Farms as part of Small and Medium Enterprises (SMEs) are critical to the development of any economy as they usually form the bulk of economic activity and provide jobs for about $75 \%$ of the workforce of any country especially in the developing countries in Africa [59]. Most of these SMEs in Africa do not survive their second birthday because of environmental constraints they face from global companies. These constraints include lack of capital, human resource challenges, poor financial management, marketbased challenges, unfavourable regulatory conditions and weak institutional regimes [54]. The failure rate of small business stands around 50 percent in Africa [4].
According to Namusonge et al [44] there are barriers to SMEs performance in Africa, which include lack of capital investment, infrastructure, education and training systems, encumber regulations, and in general deficiencies in knowhow and skills acquisition, constrained financial managerial capabilities, difficulty in utilizing technology which results in low productivity. In Nigeria, SMEs play an important role on economic growth, as they constitute $97.2 \%$ of the companies in Nigeria (Ministry of Trade and Investment, 2011). It is unfortunate that SMEs performances have fallen short of expectations in Nigeria [55]. The country is still characterized with alarming unemployment rate of $19.7 \%$ in 2010 and $43.67 \%$ in 2016 as well as, high level of poverty for more than half of the population still live below the poverty line [25]. This shows that SMEs are not very effective in this part Nigeria.

Generally, it is recognized that small and medium poultry enterprises interact with the business environment, which affect their growth and profitability and hence, overall performance as an organization [20]. Some of the environmental factors impacting on the performance of these enterprises are; entrepreneurial training and experience, access to credit facilities, national policy and regulatory environment, technological change, country infrastructure and markets information. In Nigeria, livestock resources consist of $13,885,815$ cattle; $34,453,742$ goats; $22.096,602$ sheep, $3,406,381$ pigs and $104,247,960$ poultry (Amos, 2006). From this figure, poultry accounted for $58.2 \%$ of the total livestock production. Nigeria has a poultry industry with about 160 million birds estimated at US\$ 250 million. The industry contributes up to $10 \%$ to the country's agricultural GDP and accounts for $36 \%$ of total protein intake of the country. The overall industry attracts investment and yields a net worth of US\$ 1.7 billion a year [4].

The poultry industry offers the quickest returns to investment outlays in livestock enterprise by virtue of its short gestation period, high feed conversion ratio alongside being one of the cheapest, commonest and best sources of animal protein in the country [50]. Poultry production is the most efficient and cost-effective way of increasing the availability of high-protein food, as eggs are known to provide the most perfectly balanced food containing all the essential amino-acid, minerals and vitamins [52]. Nigeria poultry industry contributes about $15 \%$ of the total annual protein intake with approximately $1.3 \mathrm{~kg}$ of poultry products consumed per head per annum [52]. In the past decades, there has been a recorded improvement in poultry production in Nigeria with its share of the Gross Domestic Product (GDP) increasing in absolute terms. In spite of the significance of the poultry industry to the national economy. Akintunde et al [5] established that poultry farms in Nigeria face challenges inimical to the growth of the industry. The challenges of poultry production in general are low capital base, poor financial management, inefficient management, disease and parasite, housing and marketing problems.

Consequently, farms profitability could be damaged because of inefficient financial management practices. The 
Poultry farms have often failed due to the lack of knowledge of efficient financial management practices [10]. Moreover, the uncertainty of the business environment causes the farms, which are predominantly SMEs, to rely excessively on equity and maintain high liquidity and these financial characteristics affect profitability. Financial management in SMEs is noticed by these researchers $([10,22,30,42,50,52,54,4,67])$. However, in many previous studies about financial management practices still have some limitations and more so little or no research work has been carried on financial management practices on performance of the poultry industry especially in a developing country like Nigeria. Performance is one of the most concerned goal of enterprise owners, therefore studying about relations between financial management practices and Poultry industry performance will have more belief in the effectiveness of financial management and to be more helpful in understanding the financial management practices of not only Poultry industry but related businesses in Ogun State, Nigeria.

\subsection{Statement of the Problem}

In Nigeria, defining the research problem of the SMEs and specifically the poultry industry may begin with a consideration of the typical characteristics of management staff and structure. Most SMEs do not have any organizational structure and this can consequently be narrowed down to SMEs not having financial management set ups such that the finance function can be structured along financial management practices of funds sourcing or utilization. SMEs do not appoint financial managers to be in charge of financial management of the company as the owner-managers with the assistance of the accountant (accounts Clerk) control financial matters of the company. However, most owner-managers and farm managers have no formal training in management skills, especially financial management.

The SMEs in Nigeria have not been surviving as most SMEs collapse with the economic meltdown of between 2005 and 2009. The Poultry industry did not fare better as the competition for poultry inputs reached its climax in 2016 when the Federal Government of Nigeria banned the importation of grains which is about $50 \%$ single cost in poultry production and thus survival becomes a function of efficiency measurement where the Break-Even analysis became relevant more than ever before. [47]

Lack of knowledge of financial management combined with the uncertainty of the business environment often lead SMEs to serious problems regarding financial performances. Regardless of whether owner-manager or hired-manager, if the financial decisions are wrong, profitability of the company will be adversely affected. Consequently, SME profitability could be damaged because of inefficient financial management

Available empirical studies in Nigeria on management issues associated with poultry disease and performance are mostly descriptive analysis on assessment of prevalent diseases and mortality in chicken layers; evaluation of biosecurity status of poultry farms; evaluation of awareness and biosecurity practices towards highly pathogenic avian influenza. Also, literature is vast with the economic analysis of poultry production in Nigeria $([17,64,65])$. However, none of these studies has considered the assessment of financial management practices and its effect on poultry farm performance in Nigeria. Based on this identified gap, this study will examine the effect of financial management practices on performance of selected Poultry farms in Ogun State, Nigeria. and then, to analyse measures for improving SME profitability in Nigeria by using efficient financial management tools and utilization of such tools.

\subsection{Objective of the Study}

The main objective of this study is to examine the effect of financial management practices on performance of Poultry industry in Ogun State, Nigeria. And specifically to evaluate the effect of financial management practices on profitability of SMEs in the Poultry industry of Ogun State

\subsection{Hypotheses}

The hypothesis tested in this study:

$\mathrm{H}_{\mathrm{o} 1}$ : There is no significant effect of financial management practices on the Profitability of SMEs in the Poultry industry of Ogun State, Nigeria.

\section{Literature Review}

\subsection{Conceptual Review - Small and Medium Scale Enterprises (SMEs) as Poultry Industry}

A small and medium enterprise (SME) was introduced as far back as the late 1940s with the primary aim of improving trade and industrialization in the e developed nations. [48]. The definitions of SME are usually derived in each country, based on the role of SME in the economy, policies and programs designed by particular agencies or institutions empowered to develop SME. For instance, a small business in the developed economies of countries like Japan, Germany and United States of America (USA), may be a medium or large-scaled business in a developing economy like Nigeria. Moreover, the definition of SME also varies overtime from agencies or developing institutions to another, depending on their policy focus.

Generally, SME can be defined based on certain criteria including, turnover, number of employees, profit, capital employed, available finance, market share and relative size within the industry The definition can be based on either some quantitative or qualitative variables. Quantitative definitions mainly express the size of enterprises, mainly in monetary terms such as turnover, asset value, profit, as well as quantitative index like number of employees. $([15,11])$ 
Table 1. Definition of Small, Medium and Large-Scale Companies.

\begin{tabular}{llllll}
\hline \multirow{2}{*}{ Category } & \multicolumn{2}{l}{ UK (1975 Companies Act) } & European Union (EU) 1995 & \multicolumn{2}{l}{ Nigeria (2003) National Council of Industry } \\
\cline { 2 - 6 } & $\begin{array}{l}\text { Turnover } \\
\text { millionf }\end{array}$ & $\begin{array}{l}\text { Workforce } \\
\text { Number }\end{array}$ & Workforce Number & $\begin{array}{l}\text { Workforce } \\
\text { Number }\end{array}$ & $\begin{array}{l}\text { Total Cost Including Working Capital } \\
\text { But Excluding Land m'Naira }\end{array}$ \\
\hline Small Scale & $<1.4$ & $<50$ & $10-49$ & $11-35$ & $1-40$ \\
Medium Scale & $1.4-5.7$ & $50-250$ & $50-250$ & $36-100$ & $40-199$ \\
Large Scale & $>5.7$ & $>250$ & $>250$ & $\geqslant 101$ & $\geqslant 200$ \\
\hline
\end{tabular}

Source: Researcher's Field Survey (2019). National Council of Industry (2003). CBN Guideline on Small and Medium Enterprise Investment Scheme (SMEEIS, 2006). IFC (2006)

In most economies, smaller enterprises are much greater in number. In Nigeria, the Poultry Industry is almost $100 \%$ SMEs. In many sectors, SMEs are also responsible for driving innovation and competition. Globally SMEs account for $99 \%$ of business numbers and $40 \%$ to $50 \%$ of GDP. ([66], $\mathrm{P}[56])$

The development of viable SMEs in Nigeria has over the years been challenged by a number of harsh economic conditions which characterise the Nigerian business environment. Some of these challenges have been outlined to include informal sources of finance still remain the major source of funding for SMEs in Nigeria including personal saving and borrowing from friends, extended families and various credit bodies. Next is the fact of huge dependence on owners entrepreneurial skills. Thirdly, there is the challenge of inadequate (or outright lack of) infrastructural and institutional support, this includes electricity, portable water, feeder roads and security networks while the judiciary is still weak at protecting SME growth and development in Nigeria. And incessant political conflicts, ethno-religious conflicts, as well as poor governance and accountability in public service, have all functioned to make the Nigerian business environment very shaky and unreliable. [19].

\subsection{Financial Management Practices}

The term Finance is traditionally defined as the study of funds management and how these funds are directed in order to achieve a particular objective of an entity (Chandra, 2016). Chandra (2016) states that the objective of proper financial management is to make the most of returns that associate with reducing of financial risks at the same time. Financial management practices are the central to the success of any small business [14]. Financial literature suggests that optimum application and commitment towards financial management practices result in an increased farm's performance. The financially well-managed farms are operationally efficient [13]. The ability of SMEs to develop, grow, sustain and strengthen themselves is heavily determined by their capacity to access and manage finance [1]. Inefficiencies in financial management practices result in poor financial performance and eventually lead to failure of SMEs [34].

\subsubsection{Annual Budget Process}

The systems of annual budget process have been identified to be universal and have been considered as an essential tool for financial planning. Kerosi [36] argues that, the main role of annual budget process is to provide a projection and framework for incomes and expenses over periods of time. According to Blumentritt [11], annual budget process is defined as the process of allocating an organization's financial resources to its units, activities and investments.

Budgets are a source of income control used to establish priorities and set targets in order to provide direction and coordination, so that business objectives can be turned into practical reality, to assign responsibilities to budget holders (managers) and allocate resources, to communicate targets from management to employees, to motivate staff, to improve efficiency and to monitor performance. Any good budget process needs to attain three important objectives, namely, maintenance of fiscal discipline, attaining allocative efficiency, and operational or technical efficiency. Annual cash budget process entails a plan that outlines the expected cash receipt and cash payments and is used to show the current financial position of the organization at a particular time. Management of fixed assets entails keeping track and safeguarding of the non-current assets of the entity. While capital structure management is the planning and management of the entity's capital structure and Risk Management on the other hand ensures that the organization remains stable even when faced with financial uncertainties. These practices do not work as separate entities and ought to be all integrated so as to have a positive influence on the financial performance.

Ekpenyong [18] states that annual budget process is a tool of financial management which regularly prepares performance plans and budget requests that describe performance goals, measures of output and outcomes in various activities aimed at achieving performance goals in a defined period of time. This helps in the sense that annual plans set forth in measurable terms form the levels of performance for each objective in the budget period.

Budgeting process pushes managers to take time to create strategies, targets and goals before activity begins. Budget preparation helps management focus on the next month or the entire coming year. The budgeting process forces managers to assess current operating conditions and aids in forecasting and implementing needed changes [8]. Budget preparation is also an excellent vehicle with which to work with all supervised personnel by requesting their managers and their staffs. At the end of a period the budget helps managers evaluate 
performance, locate problematic areas, bottlenecks and provide solutions to these problems. Budgets analysis should be a regular and ongoing part of management duties because helps chart the course of operations and provides a means to evaluate performance once the task has been completed. If realistic goals have been established comparing the actual results with budgeted targets can help management assess how well the organization performed [39].

Budgets represent one of the accounting measures which are used to assess a company's performance. The reward system of the organization (pay, promotion) is often linked to the achievement of certain levels of performance, frequently measured in accounting terms. It is conventionally assumed that by establishing formal performance measurement and rewarding individuals for their performance they will be encouraged to maximize their contribution towards the organization's objectives [29]. Lucey [38] view annual budget process as a quantitative statement, for a defined period of time, which may include planned revenues, expenses, assets, liabilities and cash flows. A budget provides a focus for the organization, aids the co-ordination of activities and facilities control while it is defined as a financial or quantitative statement prepared and approved and approved prior to a defined period of time. Drury (2008) view annual budget process a detailed plan that coordinates various activities within the company for further actions. Siyanbola [63] defined budget as a parameter which measures the actual achievement of people, departments, ministries and firms, while budgetary control ensures that actual results are positively or negatively in accordance with the overall financial and policy objectives of the establishment.

According to Obi [46] annual budget process is a plan quantified in monetary terms, prepared and approved prior to a defined period of time, showing the planned income to be generated and expenditure to be incurred during that period, and the capital to be employed to attain a given objective. A budget though takes into consideration externalities is also dependent on a number of factors such as type of organization, nature of activities, purpose of the budget and limitations of government regulations. Subject to the choice of a firm, the time period of a budget can be a month, quarterly, half-yearly, full year or rolling plan. Each budget is expected to focus on the attainment of well-defined goals and objectives of the enterprise. A budget is the allocation of the resources to the operational subunits taking into account the short-term goals and the activities developed by the company. Therefore, a budget is a plan for a specific period in monetary currency that includes the estimated profit and loss needed to achieve organization goals and objectives. The profit and losses are measured considering the resources allocation to the activities. Another important concept is budgeting. "Budgeting is the process of preparing a plan, commonly called a budget" [46].

\subsubsection{Working Capital Management(WCM)}

Okoye et al [51] defined working capital management as one that is concerned with the problems emanating from attempts to manage the current asset, current liabilities and the interrelationship that exists between them. Whereas, Shin et al [61] noted that working capital management is the administration of the whole aspects of both current assets and current liabilities, which makes working capital the life blood of a company. Working capital management ensures that a company has sufficient cash flow in order to meet its shortterm debt obligations and operating expenses. Implementing an effective working capital management system is an excellent way for many companies to improve their earnings. The two main aspects of working capital management are ratio analysis and management of individual components of working capital. Ratio analysis helps the management to identify areas of focus, such as inventory management, cash management, accounts receivable and payables management.

Working capital management consists of managing working capital components; including cash, receivable, and payable and inventory management in SMEs and working capital policy used to maintain level of investment in current assets for attaining their targeted [67]. In order to understand the importance of working capital one has to understand the working capital cycle which is described as the core for working capital management. [60] Sarbapriya [60] said that working capital cycle includes all the major dimensions of business operations. It is quite clear that a bad management of a single account in this cycle might cause a big trouble for the non-living entity which might leads to its death. Therefore, the management of working capital and balance between components of working capital is extremely important for the smooth running of business. Similarly, the basic aim of financial management is to maximize the wealth of the shareholders and in order to (201 achieve this; it is necessary to generate sufficient sales and profit.

However, sales do not convert in to cash instantly. The time between purchase of inventory items (raw material or merchandise) for the production and their conversion into cash is known as operating cycle or working capital cycle. Therefore, working capital management deals with the act of planning, organizing and controlling the components of working capital (current asset and liability) like cash, bank balance, inventory, receivables, payables, overdraft and short-term loans [41].

\subsubsection{Capital Structure Management (CSM)}

Capital Structure Management (CSM) means overseeing the capital structure of an organization. A company's capital structure means the various funding combination and its sources. There are two key funding mix of debt and equity, while debt could be short-term or long-term, equity could be number of shares of common stock or preferred stock or retained earnings. Short-term debt such as working capital requirements is also considered to be part of the capital structure When determining a company's cost of capital, as a strategy under stable market conditions, a company can compute its optimal mix of capital. A company's optimal mix of capital is the combination of sources of capital that yields the lowest weighted average cost of capital, 
which is the weight of the costs of each component of the capital structure in relation to the overall total amount and this is known as the company's weighted average cost of capital (WACC) which is then used to calculate the net present value (NPV) of capital budgeting for corporate projects. A lower WACC will yield a higher NPV, so achieving a lower WACC is always optimal. [69]

\subsection{Theoretical Review}

There are several theoretical review that provides the basic theoretical assumptions for the study on Poultry industry performance and the focus on these relevant theories that can be applied to the study variables and concepts in order to come up with a logical linkage between the variables. The affected theories are; The Contingency Theory, Shareholder Theory, and Pecking Order Theory.

\subsubsection{Contingency Theory}

The contingency theory of leadership was proposed by the Austrian psychologist Fred Edward Fiedler in his 1964 article, "A Contingency Model of Leadership Effectiveness" [23]. The contingency theory emphasizes the importance of both the leader's personality and the situation in which that leader operates. The theory holds that there are various contextual factors that determine how an organization operates such as the technology and external environment. As described by Chenhall [16], that these factors will affect the organizational structure, which will then influence the design of the financial system.

Pike explained the contingency theory in relation to business management to mean that the efficiency of resource allocation is not simply a matter of adopting complex, theoretically higher investment techniques and procedures but also attention must be given to the fit between the corporate setting and the design and operation of the capital budgeting system. Three characteristics (namely degree of professionalism, the history of the organisation and the management style) of the corporate setting which are assumed to be related with the design and operation of a firm's capital budgeting system have been emphasised.

\subsubsection{Shareholder Theory}

This theory was introduced by Edward Freeman in 1988 and defines the primary duty of a firm's managers as the maximization of shareholder wealth. The theory enjoys widespread support in the academic finance community and is a fundamental building block of corporate financial theory. However, the shareholder model has been criticized for encouraging short-term managerial thinking and condoning unethical behaviour. Smith (2003) notes that critics believe shareholder theory is geared toward short-term profit maximization at the expense of the long run. Freeman et al [24] assert that shareholder theory involves using the prima facie rights claims of one group shareholders to excuse violating the rights of others. Opponents of shareholder theory often recommend that firms balance the interests of shareholders against those of employees, customers, and other stakeholders when making business decisions
(Freeman, 1984). The criticisms are understandable because many proponents of shareholder theory, in a stylized version of the model, exhort managers to maximize the firm's current stock price [35]. Wealth maximization is inherently a longterm goal; the firm must maximize the value of all future cash flows and does not condone the exploitation of other stakeholders [32].

\subsubsection{Pecking Order Theory}

Pecking order theory was first introduced by Donaldson in 1961 before it was modified by Stewart C. Myers and Nicolas Majluf in 1984. The theory suggests that firms have a particular preference order for capital used to finance their businesses [43]. Owing to the information asymmetries between the firm and potential investors, the firm will prefer retained earnings to debt, short-term debt over long-term debt and debt over equity. Myers [43] argued that if firms issue no new security but only use its retained earnings to support the investment opportunities, the information asymmetric can be resolved. That implies that issuing equity becomes more expensive as asymmetric information insiders and outsiders increase. Firms whose information asymmetry is large should issue debt to avoid selling under-priced securities. The capital structure decreasing events such as new stock offering leads to a firm's stock price decline. An announcement of increasing capital structure events is received by the market as good news because financial intermediaries like investment business can become insiders to monitor the firm's performance. Managers may have inside information that is not known to the market. Insider investors have more information about the true distribution of firm returns than outsiders. Insider investors tend to limit the use of equity in order to retain control of the firm. Moreover, the risk of the firm's return is unknown to investors. They are forced to rely on noisy signals such as the firm's level of capital structure to determine the risk of their investment and firm's value may be under-priced by the market [43].

\subsection{Empirical Review}

The study of Okoye et al [51] examined the link between working capital management and SMEs profitability. Their study revealed that there is a significant relationship between working capital management and SMEs profitability. and that there is a significant relationship between working capital management and profitability. Falope et al [21], revealed that working capital management correlate with small firm performance. Gill et al [26], revealed that there is a significant relationship between working capital management and profitability. The study of Akindele et al [3] revealed that there is a significant relationship between working capital management and profitability and that there is a significant relationship between working capital management and profitability.

Akindele et al [3] studied the effect of working capital on the profit performance of the Nigerian cement sub-sector. The study investigated four (4) cement companies quoted on the Nigerian Stock Exchange for the period of 8 years, from 2002-2009. The study shows non-significant negative effect 
of number of days account receivable are outstanding on firm profitability. It also reveals a significant positive effect of cash conversion cycle on the profit performance of the selected farms

Falope et al [21] examined the impact of working capital management on corporate profitability of non-financial service companies quoted on the Nigerian Stock Exchange (NSE). The study examined fifty companies using data over the period 1996-2005. The study found a negative relationship between net operating profit (dependent variable) and the independent variables (average payment period, cash conversion cycle, average collection period and inventory turnover). The result also shows that firm size does not affect the financial performance. Mathuva [41] examined the impact of working capital management on corporate profitability of firms in Kenya. The study analysed a sample of 30 firms quoted on the Nairobi Stock Exchange for the periods 1993-2008 using the ordinary least square (OLS) estimation technique. He finds a negative impact of working capital management on firm performance. The study further shows a significant positive impact of average payment period on the performance of Kenyan firms. Sarbapriya [60] studied the effect of working capital management on the profit performance of Indian manufacturing firms using a sample of three hundred and eleven firms. The study covered a period of 14-years. He finds evidence of significant positive impact of working capital management on the profitability of Indian manufacturing firms.

Working capital can be measured with cash conversion cycle, which consists of stockholding period, debtors' collection period and creditors' payment period. The greater investment in working capital (the longer cash conversion cycle) leads to reduction in the firm's profitability. Shin [61] investigated the relationship between cash conversion cycle and the profitability of the firms for a sample of companies listed in the United States Stock Exchange during the period spanning from 1975 to 1994; they found a significant negative relationship between the value of the companies and the cash conversion cycle of the same companies. In addition to this Shin [61] intended to come up with the determinants of working capital and found that its management is correlated in a positive way to firm size. They also established that industry concentration does not affect working capital management and that a greater compensation paid to the CEO of the firm definitely improves the company's management of working capital. These results suggest that working capital management has an important impact on the profitability of the firms.

Shubita [62] model the effects of working capital management practices on firm value, they do not provide evidence on whether firms actually do maximize their value by their working capital management choices. The study that comes nearest to addressing this issue is the study by Shin [61], which examines the relation between different accounting profitability measures and net trade cycles, a summary efficiency measure of a firm's working capital management. Most of the empirical studies support the traditional belief about working capital and profitability, that reducing working capital investment would positively affect the profitability of firm by reducing the proportion of current assets in total assets. For the first time, IFC [30] investigated the relationship between the net trade cycle as a measure of working capital and return on assets, and found a negative relationship between the length of net trade cycle and return on assets. In order to validate the results of IFC [30], on large sample and with longer period of time, Zakari [68] examined the relationship between aggressive working capital management and profitability of Nigerian companies using cash conversion cycle as a measure of working capital management. The results showed that more aggressive working capital management is associated with higher profitability.

Measures of corporate performance are numerous. In all of the analysis on financial performance measures, three elements of the financial statements are considered key to all situations, namely the statements of income (the Profit or Loss Account), the Statement of Financial Position (Balance Sheet) and the Statement of Cashflow. The performance measures in the Poultry industry in Nigeria like most SMEs can be measured basically by examining the Turnover, Gross Profit, Contribution Margin and Return on Sales

Profitability Measures

Turnover/Net Sales Revenue

\section{Contribution Margin $=($ Net Sales Revenue - Variable Costs $) /$ Net Sales Revenue}

Operating Margin $=($ Net Sales Revenue- Variable Cost - Direct Fixed Cost $) /$ Net Sales Revenue.

$$
\text { Net Profit Margin }=(\text { Net Sales Revenue }- \text { Total Cost }) / \text { Net Sales Revenue }
$$

Net profit is the bottom line, the amount of cash left over after paying all the bills and it defines the percentage of revenue that was profit

\section{Return on Sales $=($ Net Profit $/$ Net Sales Revenue $) \%$}

Production Efficiency - Feed Conversion Ratio, Liveability, Production Life Cycle

\subsection{Justification for the Study}

In terms of financial management practices, most previous researchers have focused on examining, investigating and describing the behaviour of SMEs in practicing financial management. The specific areas of financial management practices including working capital management, fixed asset management, annual budgeting process and capital structure 
management have long attracted the attention of researchers [58]. Their findings are mainly related to exploring and describing the behaviour of SMEs towards financial management practices. Although they provided such descriptive statistical data and empirical evidence on SME financial management practices in manufacturing industry but failed to consider SMEs farming industry, it appears that there still gaps in the literature, which is being addressed.

Firstly, most empirical evidence comes from the developed economies such as the United States of America (USA), the United Kingdom (UK), Canada and Australia [37]. And the developed economies can be further latched onto for expanding the frontier of studies relating to financial management practices and SMEs performance in farming poultry industry in Nigeria. Secondly, most previous researchers focus on investigating and describing financial management practices whereas there has been little research examining the impact of financial management practices on SMEs performance in Nigeria [33].

These are major gaps and it is difficult to convince business financial management practitioners of the need for changes in practices until empirical evidence of the effects of financial management practices on the profitability of SME is provided and the relationship between the two variables are discovered. Based on previous research findings and recognition of these gaps, a study of the impact of financial management practices on SMEs performance of poultry farms in Ogun State, Nigeria is justified and a model of the impacts of financial management practices and its effect on SMEs performance should be developed and tested by using the empirical data from Nigeria. However, studies on the effect of financial management practices on Poultry industry in Ogun State are scanty considering individual constructs of financial management practices majorly like annual budget process, capital structure management and working capital management. Based on this identified gap, this study focused on the effect of financial management practices on performance of selected Poultry farms in Ogun State, Nigeria.

\section{Methodology}

\subsection{Population}

150 structured questionnaires were administered and 122 responses in a combination of direct interview, online questionnaires and paper copies were filled and returned from across the six zones in Ogun State as mapped out by the Poultry Association of Nigeria, Ogun State chapter. This represents a response rate of $81.3 \%$. According to Mugenda and Mugenda (2003) as cited by Ngwiri et al [45], a response rate of $50 \%$ or more is adequate. Babbie [9] also asserted that return rates of $50 \%$ are acceptable to analyse and publish, $60 \%$ is good and $70 \%$ is very good. Based on these assertions from renowned academicians, the responses rate for this study of $81.3 \%$ is considered sufficient for making inferences and drawing conclusions. Table 2 illustrates the rate of responses from the SMEs poultry farms as contained in the Farm Registration list with Department of Veterinary Services (DVS) in conjunction with the Poultry Association of Nigeria, Ogun State chapter.[56].

Data analysis for this study was done in two stages: the descriptive and inferential analysis. The first stage (the descriptive analysis) features descriptions of the properties of the data to show the variations in responses of the study's participants using such tools as frequencies and percentage distribution tables, bar charts, means and standard deviations. It will also provide the views and opinions of the respondents on financial management practices and Poultry farms performance.

The second stage (the inferential analysis) is the analysis of the responses on the quantitative data and the relationships. This was carried out using statistical tools of multiple regression method of analysis using SPSS (Statistical Package for Social Sciences) software version 22.0 to test the effect link between the independent variables on the dependent variable.

The variables for this study operationalized thus:

$$
\mathrm{Y}=\mathrm{f}(\mathrm{X})
$$

Where $\mathrm{Y}=$ PF Performance (PFP), and; $\mathrm{y}_{1}=$ Profitability (PFT)

$\mathrm{X}=$ Financial Management Practices (FMP)

$\mathrm{X}=\left(\mathrm{x}_{1}, \mathrm{x}_{2}, \mathrm{x}_{3}\right)$

$\mathrm{x}_{1}=$ Annual Budget Process (ABP)

$\mathrm{x}_{2}=$ Capital Structure Management (CSM)

$\mathrm{x}_{3}=$ Working Capital Management (WCM)

Hypothesis

$$
\begin{gathered}
\mathrm{Y}=\mathrm{f}\left(\mathrm{x}_{1}\right) \\
\mathrm{y}_{1}=\beta_{0}+\beta_{1} \mathrm{x}_{1}+\varepsilon_{\mathrm{i}}
\end{gathered}
$$

$$
\mathrm{PERF}=\beta_{0}+\beta_{1} \mathrm{ABP}+\beta_{2} \mathrm{CSM}+\beta_{3} \mathrm{WCM}+\varepsilon_{\mathrm{i}} \text { Main Model }
$$

\subsection{Researcher's Conceptual Model}

The conceptual model was developed to establish the relationship between the independent variables (Financial Management Practices components) and the dependent variable (Poultry Industry Performance) as elucidated in the gap of the study.

Table 2. Distribution of Questionnaire/ Response Rate.

\begin{tabular}{lll}
\hline Categories & Frequency & Percentage\% \\
\hline Copies of questionnaire administered & 149 & 100 \\
Copies of questionnaire filled and returned & 122 & 81.3 \\
Copies questionnaire not returned & 28 & 18.7 \\
\hline
\end{tabular}

Source: Researcher's Field Survey, 2019 


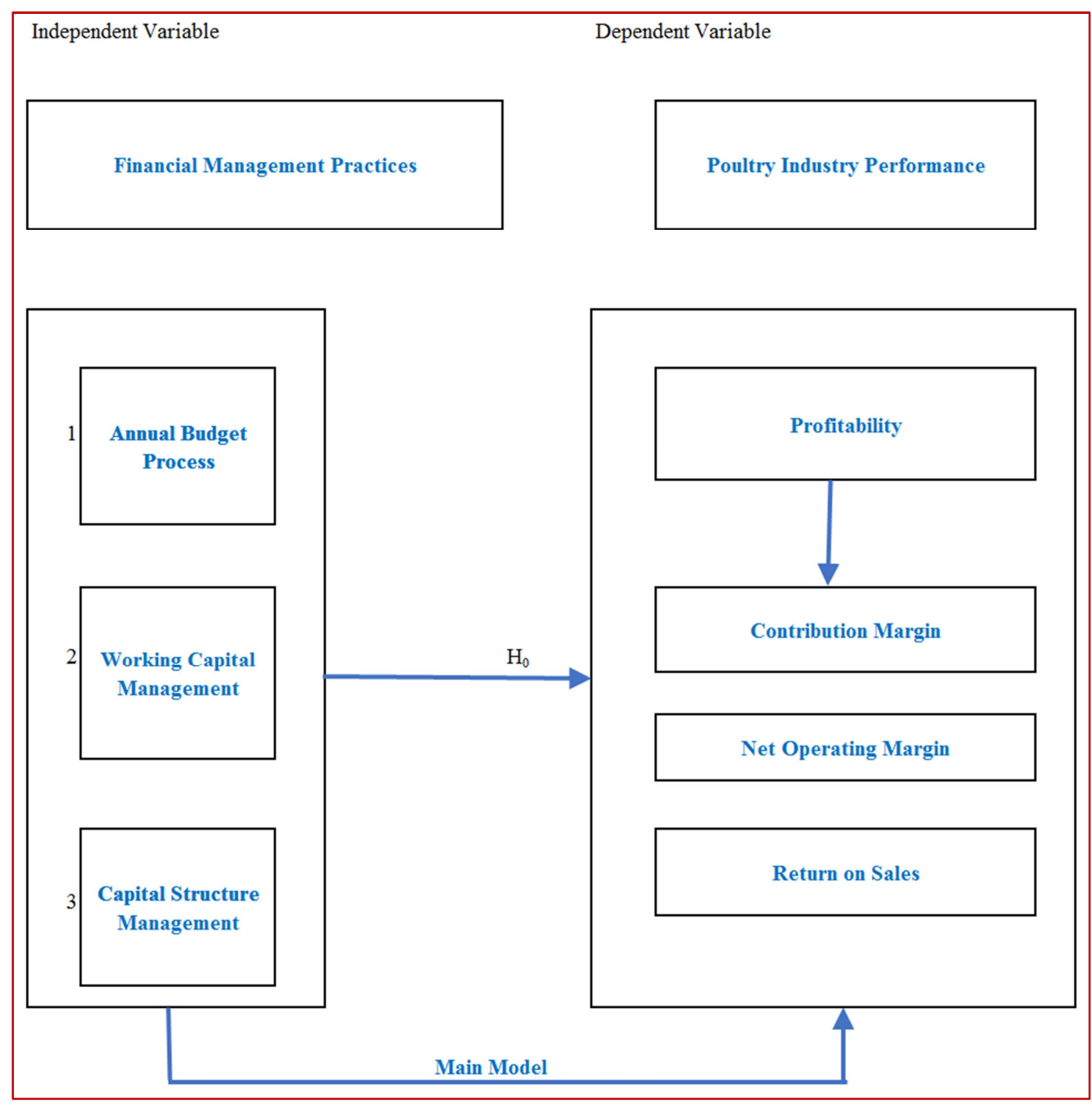

Source: Researchers conceptual model (2019)

Figure 1. Conceptual Model Summary.

The independent and dependent variable for this research is financial management (X) and Poultry Farms performance (Y) respectively. The independent variable financial management (X) is measured using the following dimensions: annual budget process, working capital management and capital structure management while the dependent variable is measured by the key variable of profitability - Contribution Margin, Net Operating Margin and Return on Sales.

\section{Results and Discussion of Findings}

\subsection{Data Analysis}

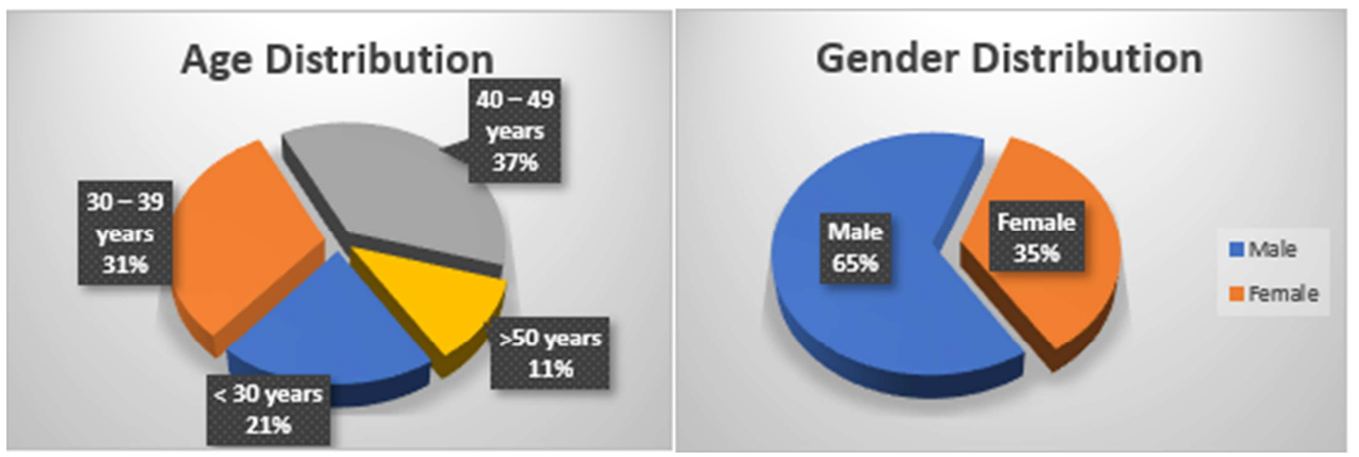




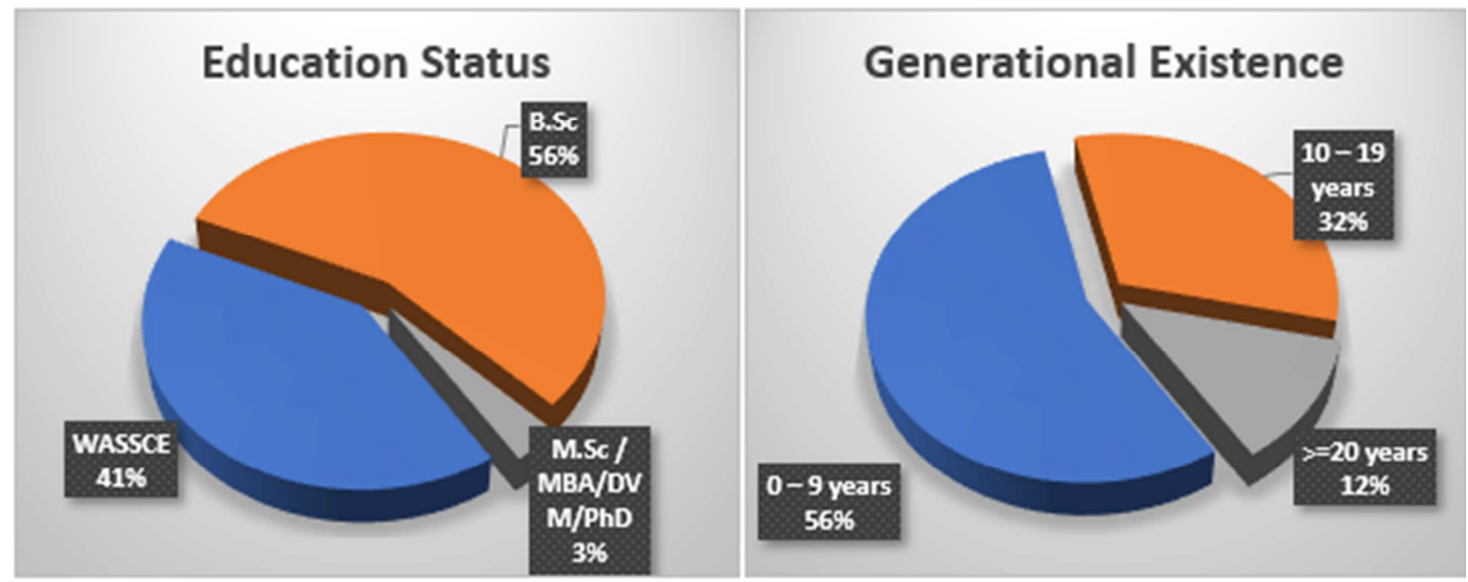

Source: Field Survey, 2019

Figure 2. Demographic Characteristics of Respondent.

Inferential Analysis

In order to determine the effect of financial management practices on performance of poultry selected farms in Ogun State, Nigeria, a multiple regression was done

\subsection{Test of Hypothesis}

Research Objective: evaluate the effect of financial management practices on profitability of SMEs in the poultry industry of Ogun State

Research Question: In what way does financial management practices affect the profitability of selected poultry in Ogun State, Nigeria?

Research Hypothesis (Ho): There is no significant effect of financial management practices on the profitability of SMEs in the poultry industry of Ogun State, Nigeria.

Table 3. Regression Estimate.

\begin{tabular}{lllll}
\hline \multirow{2}{*}{ Variable } & Model & & & Prob. \\
\cline { 2 - 5 } & Coefficient & Standard Error & $\boldsymbol{t}$-stat & .003 \\
\hline Constant & 1.561 & .511 & 3.057 & .220 \\
ABP & .103 & .084 & 1.233 & .744 \\
CSM & .024 & .073 & .327 & .425 \\
WCM & .109 & .136 & .801 & \\
$R^{2}$ & .289 & & & \\
Adjusted $R^{2}:$ Overall & 0.258 & & & \\
F-Stat & $9.407(0.000)$ & & & \\
\hline
\end{tabular}

Dependent Variable: Profitability * significant at 5\%

Source: Researcher's Study, 2019

Model

$$
\begin{gathered}
\mathrm{PFP}=\beta_{0}+\beta_{1} \mathrm{ABP}+\beta_{2} \mathrm{CSM}+\beta_{3} \mathrm{WCM}+\varepsilon_{\mathrm{i}} \\
\mathrm{PFP}=1.561+0.103 \mathrm{ABP}+0.024 \mathrm{CSM}+0.109 \mathrm{WCM}
\end{gathered}
$$

The regression estimates of the model shows that financial management practices measured by annual budgeting process (ABP), capital structure management (CSM) and working capital management (WCM) positively affects performance measured by profitability (PFP). This is indicated by the signs of the coefficient. $(=\beta 0=1.561 ; \beta 1=0.103 ; \beta 2=0.024$; $\beta 3=0.109 ; \beta 4=0.156$ and $\beta 5=0.218$ ). Also, annual budget process has a positive insignificant effect on profitability $(\beta=$ $0.103, t=1.233, p=.220)$, capital structure management has a positive insignificant effect on profitability $(\beta=0.024, t$ $=.327, p=.744$ ) and working capital management has a positive insignificant effect on profitability $(\beta=0.109, t$
$=.801, p=.425$ ).

The Adjusted $R^{2}$ of the model showed that $25.8 \%$ of the variations in profitability of selected poultry businesses can be attributed to financial management practices proxies used in this study, while the remaining $74.2 \%$ of the variations in profitability of selected poultry farms are caused by other factors not included in this model. The overall F-Statistics is 9.407, while the P-value of the F-Statistics is 0.000 which is less than 0.05 adopted for this work. The study rejected the Null hypothesis, implying that financial management practices does exert a significant effect on profitability of SME poultry industry in Nigeria. Hence, the null hypothesis may not be accepted.

\subsection{Discussion of Findings}

The purpose of this study was to determine the effect of financial management practices on performance of poultry 
industry in Ogun State, Nigeria. Primary data were used for the analysis. From the descriptive regression analysis, the following are the findings:

The model one summary shows that the adjusted coefficient of determination is 0.258 . This indicates that $25.8 \%$ variation in profitability is attributable to financial management practices as represented by annual budget process (ABP), capital structure management (CSM) and working capital management (WCM). While the remaining $74.2 \%$ variation in profitability of selected poultry farms can be attributed to other variables not covered in this model. annual budget process has a positive insignificant effect on profitability $(\alpha=0.103$, $t=1.233, p=.220$ ), capital structure management has a positive insignificant effect on profitability ( $\alpha=0.024, t=.327, p=.744)$, working capital management has a positive insignificant effect on profitability $(\alpha=0.109, t=.801, p=.425)$. That is, when there is good annual budget process, well-structured capital management and working capital management, there will be an increase in profitability of poultry farms in Ogun State, Nigeria.

The result from the analysis is in line with the study of Pena [57] where they stated in the importance of financial management practices in the agricultural business in order to boost their performance. They stated that most agricultural businesses don't thrive because the managers or owners focus more on agricultural production than the financial side of it. This study has been able to prove the essence of financial management practices in order to ensure the better performance and sustainability of the business. Gloy [27] also attest to this study from their research conducted on New York Diary farm that financial management practices like net cash income, check book balances, gross sales, accrual net farm income and return on assets were been used by their respondents in analysing their business performance. The farmers from the study also noted that developing an accurate budget is an important aspect of a business analysis because budget is a critical component of profitability analyses and cash flow projections

\subsection{Implications of Findings}

The findings of this study have implications for Government and her agencies, the general public and prospective researchers. This study provides empirical evidence that financial management practices positively affects performance of poultry industry farms in Ogun State, Nigeria. Hence, the implications are discussed here:

\subsubsection{Implications to Government}

Model one suggests that financial management practices have a positive effect on profitability which will make government and her agencies to ensure that more funds are pumped into the agricultural sector of the state because they are performing well. Since a good financial management of these SMEs will ensure better performance and profitability, therefore, government will be more encouraged also to do more for the agricultural businesses especially the SMEs

\subsubsection{Implications to Industry}

Model two suggest that financial management practices have a positive effect on cash solvency, as such; the SMEs in the poultry industry must do everything possible to ensure a good cash flow system is maintained in their business in order not to run out of business. Regular maintenance of their working capital is very necessary to study their inventory, receivables and payables and take note that they are at par to break even.

\subsubsection{Implications to Society}

When the poultry industry advanced in aspect of performance and effectiveness, it enables them to sustain their contribution to being a big player in employment opportunities in the Livestock industry and contribute to the development and improvement of the economy. Accordingly, the environment within which the SMEs function becomes instantaneous beneficiary in terms of benefit that will roll out from them

\subsubsection{Implications to Management Practice}

The model suggest that financial management practices have a positive effect on economic value added, a good structured financial management system in these SMEs will ensure economic value added. Economic value will increase as they adopt good financial management which will continually grow their economic profit and worth financially. Economic value added can also be used as an internal management performance measure that will help them compare net operating profit to their total cost of capital.

\subsubsection{Implications to Research}

The implication of this study to research is that the variables analysed can individually be expanded and backward analysis can reveal the weight that each of the three variables of profitability, cash solvency and economic value added contribute to the overall performance of the poultry industry and by extension the Livestock sub-sector.

\section{Conclusion and Recommendation}

\subsection{Conclusion}

The result of regression estimates of the model revealed that all proxies of financial management practices have a significant positive effect on profitability of poultry industry in Ogun State. This is evident from the coefficient of $+0.103,+0.024,+0.109,+0.156$ and +0.218 . The adjusted $R^{2}$ model shows $25.8 \%$ variations in profitability (PFP) is attributed to the financial management practices proxies of ABP, CSM, and WCM while the remaining $74.2 \%$ is caused by other explanatory factors outside this model, the p-value of its F-statistics of 0.000 which is less than the acceptable 0.05 level of significance; implying that the model is statistically significant. The study examined the effect of financial management practices on selected poultry industry farms 
in Ogun State, Nigeria. The regression estimates show the effect of financial management practices on profitability which indicates that the financial management practices has a positive significant effect on profitability.

The poultry industry in Nigeria is a totality of a number of players with varying financial management knowledge and challenges. Since only a few respondents in managerial positions were involved in this study in Ogun State, the sample may not be a representative of all industry players in Nigeria while the results of the study may also be limited by time, deeper understanding and financial constraints.

This study focuses on poultry industry in Ogun State, Nigeria, it is suggested that future studies should extend the scope of study and explore other states and also other agricultural industries in the country in order to be able to generalize the conclusions in Nigeria. Also, other variables of financial management practices not captured in this study should be worked on while each of the variables can further be isolated and comprehensively diagnosed including applicable software applications that can be adapted/adopted in the poultry industry.

\subsection{Recommendations}

Based on the findings, the study recommended that:

SMEs should ensure enhance and regularly update their accounting information system because from the responses, it showed that majority of the respondents do have an accounting information system in place but like hardware too, accounting software are being developed regularly and inclusive of other multi-dimensional farm. management software.

The annual budgeting process should be simplified since the industry is already taking benefit of this practice. Modern budgeting techniques inclusive of sensitivities analysis by the Farm Owners. and managers should be sustained in addition to the various budgetary control measures. It is only that which can be measured that can be controlled and measurement will be largely influenced by the various budgeting tools available.

SMEs should expand the coverage of financial management practices proxies like financial reporting analysis, working capital management, budget process and others like credit management, cash management and asset management in their operations in order to boost their capability in competing and growing like the big farms.

It is also very necessary to obtain knowledge about basic financial concepts by the owners of these SMEs in order to help manage their finances in case they do not have a financial expert in their farms. The lower level in the industry need to be particularly upgraded as this study was limited to top and middle level management of these farms. A healthy business is one that all the cadres of the business strata can understand and apply various financial management practices as proxied in this study.

\subsection{Contribution to Knowledge}

This study made the following contributions to knowledge:

Contribution to Literature: The study's conceptual work has extended the frontiers of knowledge on the effect financial management practices on performance of poultry industry farms in Ogun State, Nigeria by introducing the issue of budgeting in the poultry industry and also working capital management which will help SMEs to monitor and track their financial transactions in order to boost their finances. With that, they will have good retaining policy so that business can grow regularly. Also this study examined how SMEs are thriving in Nigeria.

Contribution to Theory: This study contributed to knowledge; most works done on this research topic were hinged on both contingency theory and pecking order theory. This work introduced prospect theory that explains that individuals have irrational tendency to be less willing to gamble more with losses than profits. This will help entrepreneurs make decisions that will help them grow and support in rational utilisation of investible funds. This study contributed to existing literature by the findings that have been examined; implications of the findings, and the recommendations that have been made.

Contribution to Practice: The study investigated the effect of financial management practices on performance of poultry industry in Ogun State, Nigeria. To the best of the researcher's knowledge, this study is one of the studies considering the issue of financial management practices in the poultry industry especially among the small and medium scale enterprises. It was discovered that a wellfunctioning financial management will boost the performance of these small and medium scale enterprises and support the industry in accessing the much-needed credits from various institutional lenders of which a basic requirement if the evidence of a sound financial management practice as can be evidenced from the financial and management accounts.

Contribution to Model: This study contributed to knowledge through the model developed which shows the effect of financial management practices proxies on annual budget process, cash management structure and working capital management as well the individual effect of each proxies of financial management practices on profitability.

\section{Appendix}

Questionnaire

Financial Management Practice and Poultry Farms Performance Questionnaire (FMPPFPQ) 


\section{Appendix A: Demographic Data}

Kindly mark $[\mathrm{X}]$ in the space (s) provided:
a. Age:
[]$\leq 28 \mathrm{yrs} \quad[$ ] 29-39yrs
[ ] 40-49 yrs
[ ] 50-60yrs
[]$\geq 61 \mathrm{yrs}$
b. Gender:
[] Male [] Female
[] Others
c. Marital Status:
[] Single [ ] Married
[ ] Widow (er) [ ] Others
d. Length of Service/experience:
[ ] 0- 9yrs
[ ] 10-19yrs
[] 20-29 yrs [ ] $\geq 30 \mathrm{yrs}$
e. Nationality:
[ ] Nigerian [ ] Non-Nigerian
f. Highest Educational Level:
[ ] WASC
[ ] BSc
[ ] MSc/MBA [ ] DVM/PhD
g. Current Management Level:
[ ] Top
[ ] Middle
[ ] Finance
[ ] Planning
[ ] Others (Specify)

\section{Appendix B: Company Profile}

$\begin{array}{ll}\text { a) Name of your Organization (optional) } & \\ \text { b) Location (Zone) } & {[]} \\ \text { Ota } & {[]} \\ \text { Yewa } & {[]} \\ \text { Abeokuta } & {[]} \\ \text { Remo } & {[]} \\ \text { Mowe } & {[]}\end{array}$

c) What is your position in your business (Please circle one that applies)?

Owner

Manager

Accountant

Others, please specify

d) Do you ever attend management training programs related to financial management "' in a year? (Please circle one that applies)

Never

Rarely (from 1 to 2 attendances)

Sometimes ( 3 to 4 attendances)

Frequently (more than 4 attendances)

e) What best describes your background (Please circles one that applies)

Technical field

(Vet Doctor, Animal \& Health Technologists etc)

Vocational Skills

(Welder, Bricklayer, Carpenter, Plumber etc)

Financial management

(Accountants, Bankers etc)

Other Management Skills

(Bus Admin, Marketing, Supply Chain etc)

Others (please specify)

f) What best describes the size of your Farm (Please circles one that applies)?

Small Size $(500-4,999$ birds)

Medium Size (5000 - 50,000 birds)

Large Scale $(\geq 50,000$ birds)

Scale:

$\mathrm{SA}=$ Strongly Agree

$\mathrm{A}=$ Agree

$\mathrm{NAD}=$ Neither Agree Nor Disagree

$\mathrm{D}=$ Disagree

$\mathrm{SD}=$ Strongly Disagree 


\section{Appendix C. Independent Variable}

A. Annual Budget Process

SA A NAD D SD

1. Financial budgets are useful in providing information for making managerial decisions

2. Participation of farm owner/manager in preparing financial budgets helps the result.

3. Resource allocation/formation is fundamental to every farm planning process.

4. Forecasting of revenues and expenditures is part of farm business process.

B Capital Structure Management

5

Regular review of the organization's finances helps in making credible financial decision

6. Your organization regularly retains a percentage of their profit to be re-invested into the business.

7. Government provide flexible loans to support agriculture in your state.

8. The management increases reserves and finances after reporting net profit

C. Working Capital Management

9. Regular maintenance and updating of farm inventory records helps in farm management.

10 Proper maintenance of receivables (debtors) management is necessary in farm management

11. Proper maintenance of payables (creditors) records is essential in farm management

12. Cash-flow forecasts helping in predicting either future surpluses or deficit.

\section{Appendix D. Dependent Variable}

F. Profitability

SA A NAD D SD

21. Good financial plan boost the profitability of the business.

22. Cash flow forecasting has helped in monitoring profitability growth of the business.

23. Government and social policies on agriculture affects the profitability of SMEs in Nigeria

The drivers (factors) of profitability has ensured growth of your farm and also your industry.

29 The value generated over the business is in proportion to the value invested.

\section{References}

[1] Abe, M., Troilo, M., \& Batsaikhan, O. (2015). Financing small and medium enterprises in asia and the pacific. Journal of Entrepreneurship and Public Policy, 4 (1), 2-32.

[2] Adene, D. F. \& Oguntade, A. E. (2006). The structure and the importance of the commercial and village based poultry industry in Nigeria. FAO, Rome. 3-9.

[3] Akindele, J. A. \& Odusina, O. (2015). Working capital management and firm Profitability: evidence from Nigerian quoted companies. Research Journal of Finance and Accounting, 6 (7), $148-153$.

[4] Akingunola, R. O. (2011). Small and medium scale enterprises and economic growth in Nigeria: Assessment of financing options. Pakistan Journal of Business and Economic Review, 2 (1), 78-97. Retrieved from http://creativecommons.org/licenses/bync

[5] Akintunde, O. K., Adeoti, A. I., Okoruwa, V. O., Omonona, B. T. \& Abu, A. O. (2015). Effect of disease management on profitability of chicken egg production in Southwest Nigeria.

Asian Journal of Poultry Science, 9 (1), 1-18.

[6] Alabi, R. A. \& Isah, A. O. (2002). Poultry production constraints: The case of Esan West L. G. A. of Edo State, Nigeria. African Journal of Livestock Extension, 1 (1), $58-61$.

[7] Amos, T. T. (2006). Analysis of backyard poultry production in Ondo State, Nigeria. International Journal of Poultry Science, 15 (3), 247-250.

[8] Anderson, I. (1996). Influence of budgetary system on organisation efficiency in developing countries, Journal of management, 9 (2). 19-21.

[9] Babbie, E. (2004). Laud Humphreys and research ethics. International Journal of Sociology and social Policy, 24 (3). 12-19.

[10] Baliyan, S. P. and Marumo, D. S. (2016). Analysis of farm management skills in small-scale broiler poultry producers in Botswana. International Journal of Agricultural Economics and Extension, 4 (2): 215 - 223.

[11] Blumentritt, T. (2006). Integrating strategic management and budgeting, Journal of Business Strategy, 27 (6). 73-79. http://DOI: $10.1108 / 02756660610710382$ 
[12] Buculescu, M. M. (2013). Harmonization process in defining small and medium-sized enterprises. Arguments for a quantitative definition versus a qualitative one. Theoretical and Applied Economics, 20 (9). 103-114.

[13] Butt, B. Z., Hunjra, A. I. \& Rehman, K. U. (2010). Financia management practices and their impact on organization performance. World Applied Science Journal. 9 (9), 997-1002.

[14] Busenitz, L. W., West, G. P., Shepherd, D., Nelson, T., Chandler, G. N., \& Zacharakis, A. (2003). Entrepreneurship research in emergence: past trends and future directions. Journal of Management, 2 (1), 285308 .

[15] CBN. (2006). Small and Medium Enterprises Equity Investment Scheme (SMEEIS): An initiative of the bankers' committee. Retrieved on the 19th of December, 2018 from: Retrieved from https://www.cbn.gov.ng/

[16] Chenhall, R. H. (2003). Management control systems design within its organizational context: Findings from contingencybased research and directions for the future. Accounting, Organizations and Society, 28 (2). 127-168. Retrieved from http://www.elsevier.com/locate/aos

[17] Esiobu, N. S; G. C Onubuogu and V. B. N Okoli. (2014). Determinants of Income from Poultry Egg Production in Imo State, Nigeria: An Econometric Model Approach. Global Advanced Research Journal of Agricultural Science, 3 (7). 1-17.

[18] Ekpenyong E. E. (2014). Zero-Based Budgeting as a Management Tool for Effective University Budget Implementation in University of Calabar, Nigeria. European Journal of Business and Social Sciences, 2 (11). 11-19. Retrieved from http://www.ejbss.com/recent.aspx.

[19] Etuk, R. U., Etuk, G. R. \& Baghebo, M. (2014). Small and medium scale enterprises (SMEs) and Nigeria's Economic Development. Mediterranean Journal of Social Sciences, 5 (7) 656-662.

[20] Ezejiofor, N. \& Okoye, (2016). Comparative analysis of the investment decision of selected manufacturing firms and commercial banks in Nigeria. International Journal in Management and Social Science, 4 (8), 193-218. Retrieved from http://www.ijmr.net.in.

[21] Falope, O. I. \& Ajilore, O. T. (2009). Working capital management and corporate Profitability: evidence from panel data analysis of selected quoted companies in Nigeria. Research Journal of Business Management, 3 (3), 73-84. Doi: rjbm. 2009.73.84.

[22] Fasina, F. O., Ali, A. M. Yilma, J. M., Thieme, O. \& Ankers, P. (2012). The cost-benefit of biosecurity measures on infectious diseases in the Egyptian Household Poultry. Prev. Vet. $\quad$ Med. 103 (1), 178-191. doi: 10.1016/j.prevetmed.2011.09.016

[23] Fiedler, F. E. (1967). A theory of leadership effectiveness. New York: McGraw-Hill.

[24] Freeman, R. E., Wicks, A. C. \& Parmar, B. (2004). Stakeholder theory and the corporate objective revisited. $\begin{array}{llll}\text { Organization } & \text { Science, } 15 & \text { (3). 364-369. }\end{array}$ doi.org/10.1287/orsc.1040.0066.

[25] Gbandi, E. C. \& Amissah, G. (2014). Financing options for small and medium enterprises (SMEs) in Nigeria. European Scientific Journal (ESJ), 10 (1), 327-340. doi: org/10.19044/esj.2014.v10n1p\%25p.

[26] Gill, A., Biger, N \& Mathur, N. (2010). The relationship between working capital management and profitability: evidence from the United States. Business and Economics Journal, 1-9. Retrieved from http://astonjournals.com/bej.

[27] Gloy, B. A., La-Due, E. L. \& Youngblood, K. (2015). Financial management of New York dairy farms. Agricultural Finance and Management Journal, 2 (3). 1-37.

[28] Heise, H., Crusan, A. \& Theuvsen, L. (2015). The poultry market in Nigeria: market structures and potential for investment in the market. International Food and Agribusiness Management Review, 18 (A), 197-222.

[29] Horngren, C. T., Datar, S. M \& Rajan, M. V. (2012). Cost Accounting a Managerial Emphasis (14 ${ }^{\mathrm{TH}}$ Edition). New Jersey: Pearson Prentice Hall.

[30] IFC. (2006). Micro, small and medium enterprise: the role of small- and medium- sized enterprise in the future of emerging economies. Earth Trends 2006. World Resources Institute under a Creative Common License.

[31] Iyayi, F. I., Akinmayowa, J. T. \& Enaini, S. O. (2012). Corporate innovation and Entrepreneurial development. An international journal of arts and humanities Bahir Dar, Ethiopia, 1 (2), 280-304. Retrieved from http://www.afrrevjo.net/afrrevijah.

[32] Jensen, M. (2010). Value Maximization, Stakeholder Theory, and the Corporate Objective Function. Journal of Applied Corporate Finance. 22 (1). 32-42.

[33] Kanu, A. M. \& ATIMI-YOUSUO, M. K. (2018). Financial management practices among entrepreneurial Small and Medium Enterprises: Emperical Evidence from Yenagoa, Bayelsa State, Nigeria. International Journal of Knowledge, Innovation and Entrepreneurship, 6 (1). 34-53.

[34] Kengatharan, L. \& Yogendrarajah, R. (2017). Financial management practices and Performance of SMEs in Sri Lanka: Evidence from Jaffna District. Retrieved from https://www.researchgate.net/publication/320728716

[35] Keown, A. J., Martin, J. D., \& Petty, J. W. (2008). Foundations of finance: The logic and practice of financial management. 9th Edition. Upper Saddle River, N. J.: Pearson Prentice Hall.

[36] Kerosi E. (2018). Analysis of Budgetary Control Practices and the Management of Micro and Small Enterprises at Kangemi Town in Kenya. International Journal of Scientific and Research Publications. 8 (1).

[37] King, K. \& McGrath S. (2002). Globalization, Enterprise and Knowledge: Educational Training and Development. International Review of Education, 50 (1). 74-76.

[38] Lucey Terry (2009): Costing, Book Power Publishers. 7th Edition.

[39] Marija V.\& Neringa S. (2012) The Formation of Company Budgeting System: Importance, Problems and Solutions. Management theory and studies for rural business and infrastructure development, 1 (30). 157-170.

[40] Matemilola, S. \& Elegbede, I. (2017). The Challenges of Food Security in Nigeria. Open Access Library Journal, 4 (e4185), 1-22. Doi: org/10.4236/oalib.1104185. 
[41] Mathuva, D. M. (2010). The influence of working capital management components oncorporate profitability: A survey Kenyan Listed Firms. Research Journal of Business Management, 4 (1), 1-11. doi: org/10.3923/rjbm.2010.1.11.

[42] Mugenda, N. G., Momanyi, G., \& Naibei, K. I. (2012). Implication of risk management practices on financial performance of sugar manufacturing firms in Kenya. An International Journal of Arts and Humanities, 1 (1), 14-29.

[43] Myers, S. C. \& Majluf, N. S. (1984). Nicholas S. MajlufCorporate financing and investment decisions when firms have information that investors do not have. Journal of Financial Economics, 13 (2). 187-221. https://doi.org/10.1016/0304-405X(84)90023-0

[44] Namusonge, G. S., Muturi, W. \& Olawoye, O. O. (2016). The Role of innovation on performance of firms on Nigerian Stock Exchange. European Journal of Research and Reflection in Management Sciences. 4 (1).

[45] Ngwiri, B. M., Jomo, M. E \& Mputhia, J. G. (2016). Influence of knowledge technology Transfer on the growth of micro and small catering enterprises in Nairobi County, Kenya. International Journal of Scientific and Research Publications, 6 (1), 631-645. Retrieved from http://ijsrp.org/.

[46] Obi J. N. (2015) Budgeting and Budgetary Control as The Metric for Corporate Performance. International Journal of Sustainable development. 3 (1).

[47] Oduntan, A. (2017). Why we are partnering Edo govt - Amo farms boss. Retrieved from https://www.vanguardngr.com/2017/03/partnering-edo-govtamo-farms-boss.

[48] OECD (2004). Promoting Entrepreneurship And Innovative SMEs In A Global Economy: Towards a More Responsible and Inclusive Globalization. A Report of 2nd OECD Conference of Ministers Responsible for Small and Medium Sized Enterprise (SMEs) in Istanbul, Turkey (3-5 June, 2004).

[49] Ogunlade, I, Oduwaiye, M. O., Omotesho, K. F. \& Komolafe, S. E. (2017). Constraints Faced by Commercial Poultry Farmers in Waste Management Practices in Kogi and Kwara States, Nigeria. AGRICULTURA TROPICA ET SUBTROPICA, 50 (4). 167-174.

[50] Ojo S. O. (2003): Productivity and Technical Efficiency of Poultry Egg Production in Nigeria. International Journal of Poultry Sciences, 2 (1). 456-464.

[51] Okoye, L. U., Erin, O., Modebe, N. J \& Achugamonu, U. (2016). Working capital management and the performance of consumer and industrial goods sectors in Nigeria. 28th IBIMA Conference: Theme -Vision 2020: Innovation Management, Development Sustainability, and Competitive Economic Growth. 4408-4418

[52] Ologbon, A. C \& Ambali, I. (2012). Poultry Enterprise Combination among Sall-Scale Farmers in Ogun State, Nigeria: A Technical Efficiency Approach. Journal of Agriculture and Veterinary Sciences. Pp 8

[53] Olorunwa, O. J. (2015). Economic Analysis of Broiler Production in Lagos State Poultry Estate, Nigeria. Journal of Investment \& Management, 7 (1), 35-44. doi: org/10.1016/j.sbspro.2015.06.361.

[54] Olughor, R. J. (2015). Effect of innovation on the performance of SMEs organizations in Nigeria. Management, Scientific \& Academic Publishing, 5 (3). 90-95. doi: 10.5923/j.mm.20150503.02.

[55] Osotimehin, K. O., Jegede, C. A., Akinlabi, B. H. \& Olajide, O. T. (2012). An evaluation of the challenges and prospects of micro and small-scale enterprises development in Nigeria. American International Journal of Contemporary Research, 2 (4), 174-185. Retrieved from http://www.aijcrnet.com.

[56] PANOG Secretariat (2019). Nigeria Poultry Industry: Managing the Value Chain for National Development. Nigeria Poultry Show, Abeokuta. Ogun State.

[57] Pena, G. \& Klinefelter, D. (2017). Financial management: The key to farm-firm business management. Cooperative Extension Work in Agriculture and Home Economics, 1 (2). 15 .

[58] Rathnasiri, H. A. (2015). The Financial Management Practices of Small and Medium Enterprises in Sri Lanka. Global Journal of Contemporary Research in Accounting, Auditing and Business Ethics (GJCRA), 1 (2). 374-399.

[59] Salavou, H., Baltas, G. \& Lioukas, S. (2004). Organisational innovation in SMEs: The importance of strategic orientation and competitive structure. European Journal of Marketing, 38 (9/10). 1091-1112. Retrieved from https://www.researchgate.net/publication/235266477.

[60] Sarbapriya, R. (2011). Evaluating the impact of working capital management Components on corporate profitability: Evidence from Indian Manufacturing Firms. International Journal of Economic Practices and Theories, 2 (3), 2247 7225. Retrieved from http://www.ijept.org/

[61] Shin, H. H. and Soenen, L. (1998). Efficiency of working capital and corporate Profitability, Financial Practice and Education, 8 (2), 37-45.

[62] Shubita, M. F. (2013). Working capital management and profitability: a case of Industrial Jordanian Companies. International Journal of Business and Social Science. 4 (8). 108-115. Retrieved from http://www.cbj.gov.jo.

[63] Siyanbola, T. T. (2013). The impact of budgeting and budgetary control on the Performance of Manufacturing company in Nigeria. Journal of Business Management \& Social Sciences Research (JBM\&SSR), 2 (12). 8-16. Retrieved from http://www.borjournals.com/.

[64] Tsado J. H., Tyabo I. S., Muhammed Y., Fatoki P. \& Rilwan M. 2018) Knowledge Level and Poultry Farmers' Perception on Poultry Management Practices in Niger State, Nigeria. Nigerian Journal of Agricultural Extension, 19 (1). 32-39

[65] Ugwuoke, C. U., Ezebuiro, F. N., Okwo, C. R. \& Chukwuma, A. (2017). Management of poultry farms through the use of electronic facilities for enhanced food security in Enugu State, Nigeria. Global Journal of Biology, Agricultur and Health Sciences, 6 (4). 1-7.

[66] UNCTAD Secretariat. (2005). Improving the competitiveness of smes through enhancing productive capacity. Proceedings of Four Expert Meetings, New York and Geneva 2005.

[67] Yogendrarajah, R., Kengatharan, L. \& Suganya, S. (2017). Financial management Practices and performance of SMEs in Sri Lanka: Evidence from Jaffna district. International Journal of Accounting \& Business Finance, 3 (1), 61-72. 
[68] Zakari, M. \& Saidu, S. (2016). The impact of cash conversion cycle on firm Profitability: Evidence from Nigerian listed telecommunication companies. Journal of Finance and Accounting, 4 (6), 342-350. doi: 10.11648/j.jfa.20160406.15.

[69] Zawaideh, F. H. \& Ahmad, M. A. (2013). Effect of the cost of expert systems Implementation on the usefulness of accounting information system. International Journal of Emerging Research in Management \&Technology, 67-73. Retrieved from 